\title{
An Unusual Location of Extraosseous Ewing's Sarcoma
}

\author{
Lisanne Geens $^{a} \quad$ Johan Van Robays ${ }^{b} \quad$ Verswijvel Geert $^{c}$ \\ Kurt Van der Speeten ${ }^{a}$ \\ Departments of ${ }^{\mathrm{a}}$ Surgical Oncology, ${ }^{\mathrm{b}}$ Pathology, and ${ }^{\mathrm{c}}$ Medical Imaging, Ziekenhuis \\ Oost-Limburg, Genk, Belgium
}

\section{Key Words}

Extraosseous Ewing's sarcoma $\cdot$ Surgery $\cdot$ Chemotherapy $\cdot$ Multimodality care

\begin{abstract}
Ewing's sarcoma (ES) is the second most common malignant bone tumor in children and young adults. ES also occurs as a primary soft tissue neoplasm without involvement of bone. We report the second case of extraosseous (EO) ES emerging from the omentum and a review of the relevant literature. EO ES should be included in the differential diagnosis of soft tissue neoplasms in the abdomen.
\end{abstract}

\section{Introduction}

Ewing's sarcoma family of tumors (ESFT) represents a family of morphologically similar small round-cell neoplasms, including classic Ewing's sarcoma (ES) of the bone next to extraskeletal ES, small-cell tumor of the thoracopulmonary region (Askin tumor) and softtissue-based primitive neuroectodermal tumors (PNETs) [1, 2].

ES is the second most common malignant bone tumor of children and young adults [3, 4]. Most arise in the second decade of life, primarily among Caucasian children [5]. There is a slight male predominance [1]. Patients with localized disease have estimated 5-year overall survival rates of about $70 \%$ due to considerable progress in both local and systematic therapy during the past 4 decades $[1,6,7]$. Patients with metastatic or recurrent disease have a worse outcome; 5-year overall survival remains about $25 \%$ [8].

ES also occurs as a primary soft tissue neoplasm without involvement of bone [9]. Extraosseous (EO) ES is usually seen in the soft tissue of the lower extremities and the paravertebral region but has also been reported to arise in the gastrointestinal tract [10], kidney [11], uterus [12] and other infrequent sites [13-15]. 
We report a case of an 18-year-old female with an ES in the omentum of the abdomen and a review of the literature on EO ES [13].

\section{Case Report}

Presentation

An 18-year-old female presented with a painful swelling in the left upper quadrant of her abdomen. She became aware of this problem 4 days before presentation. There was no history of previous illness, nor did she take any medication. Physical examination revealed a tender, painful spot and palpable mass in the left upper quadrant of the abdomen.

Diagnostic Work-Up

Biochemistry indicated an elevated C-reactive protein value $(14 \mathrm{mg} / \mathrm{dl}$, normal $<1)$. Tumor marker carbohydrate antigen (CA) 125 was within normal range and the lactate dehydrogenase value was not elevated.

Ultrasonographic evaluation revealed a structure in the left upper quadrant, inferior to the left kidney measuring $7 \times 9.5 \mathrm{~cm}$. There were calcifications visible and the study in Doppler mode revealed no apparent blood flow.

Subsequent abdominal computed tomography (CT; fig. 1, fig. 2) confirmed a nodular mass in the left upper quadrant measuring $6.5 \times 7.5 \times 10 \mathrm{~cm}$. The mass was partially solid, partially cystic and had some calcifications. This mass was situated inferior to the left kidney. The spleen and pancreas were situated superior to this structure, the descending colon was posterior to this lesion and was closely related to it. The medial border of this mass was in close contact with the distal part of the transverse colon and the stomach. There was also contact with the jejunal part of the small intestine and a diffuse infiltration of the surrounding fatty tissue. There was no obvious lymphadenopathy and there were no intra-abdominal metastases.

A CT scan of the thorax did not detect thoracic metastases. Colonoscopy was normal except for a small nodule at the cecum, which anatomopathological investigations confirmed to be a submucosal lymphoid nodule.

\section{Treatment}

Excisional surgery was planned and median laparotomy was performed. Exploration revealed that the tumor was located partially in the omentum majus and partially fixed in the retroperitoneum inferior to the spleen. There was no evidence of peritoneal or hepatic metastases during surgery, nor a connection with the small or large intestine. A wide excision of the lesion with a surrounding envelope of fatty tissue was performed. Perioperative frozen section after resection suggested the presence of a mesenchymal tumor.

\section{Pathological Examinations}

Macroscopic Investigation

The specimen weighted $260 \mathrm{~g}$. It consisted of omental fat and peritoneum with a welldefined, encapsulated multinodular mass of $9 \times 5.5 \times 5.5 \mathrm{~cm}$. Cross-section revealed a solid washed-out lesion with inlying yellow zones and a macroscopic aspect of necrosis. 
Microscopic Investigation

The tumor was well defined with large inlying islands of necrosis. The tumor cells were monotonous and were closely packed together. The nuclei were of oval shape, irregular and had a notch. There was a moderate mitotic activity. The cytoplasm was vacuolated or lucid. Some cells were separated by connective tissue. Some tumor cells contained periodic acidSchiff (PAS)-positive granules in the cytoplasm (fig. 3).

\section{Immunohistochemical Studies}

The tumor that was resected during the laparotomy was positive for vimentin (fig. 4) and CD99 (fig. 5) (membranous) and negative for keratin, S-100, WT1, neuroendocrine marker (synaptophysin), inhibin, CD45, calretinin, CD117, CD34 and muscle markers (smooth cell actin and desmin). The morphologic and immunophenotype was consistent with ES. Molecular analysis by fluorescent in situ hybridization (FISH) confirmed an ES gene (EWS) rearrangement.

\section{Postoperative Course}

There were no postoperative complications. The patient was discharged from the hospital in good health on the 4th postoperative day. A whole-body positron emission tomography (PET)/CT scan was performed 4 weeks after surgery, which revealed no evidence for hypermetabolic activity.

Two months after treatment, the patient underwent laparoscopic resection of the left adnexa for cryopreservation. During this laparoscopy, 2 lesions of endometriosis were discovered and excised. The adjuvant chemotherapy regimen consisted of a 3-drug regimen including vincristine, ifosfamide and doxorubicin. There were 8 cycles planned every 3 weeks. After the first cycle, the patient had neutropenic fever which necessitated intravenous antibiotics. The subsequent second cycle was given in combination with neurokinine-1 receptor antagonist and granulocyte colony-stimulating factor (pegfilgrastim).

A CT scan of the thorax and abdomen 3 months after surgery revealed no recurrence.

After the third cycle, the patient had neutropenic fever and severe thrombopenia. The patient received intravenous antibiotics and a pool of thrombocytes. There were no other problems reported during the last 5 cycles of chemotherapy. The 6th cycle was one with a dose reduction of doxorubicin and ifosfamide (80\%). During this regimen, she received intramuscular injections of luteinizing hormone releasing hormone to protect the right ovary.

The PET/CT scan performed 6 months after chemotherapy revealed no evidence for local, lymphatic or hematogenic recurrence. Ultrasound evaluation of the abdomen and Xray of the chest revealed no recurrence 14 months after surgery.

\section{Discussion}

\section{Mesenchymal Tumors}

Sarcomas are uncommon but diverse mesenchymal malignancies that arise in bone, cartilage or connective tissues, such as muscle, fat, peripheral nerves and fibrous or related tissues (table 1). They originate from unique mesenchymal stem cells capable of multilineage differentiation along osteogenic, adipogenic or neurogenic lines. They range from indolent to highly invasive and metastatic $[1,16]$.

The term PNET was first used in 1973 by Hart and Earle [17] to denote a group of tumors thought to be derived from fetal neuroectodermal cells that had morphologic features 
of small-round-cell tumors with variable degrees of neural, glial and ependymal differentiation. There are two main categories of PNETs according to the cell of origin and location: central and peripheral. Central PNETs are derived from the neural tube and mainly involve the brain and spinal cord. Peripheral PNETs are derived from the neural crest and occur outside the central nervous system, often involving the sympathetic nervous system of soft tissue and bone. ES and PNET are regarded as two extremes of a morphologic spectrum of the same tumor entity based on similar clinical, immunohistochemical and cytogenetic profiles [12].

Biopsy is essential for definitive diagnosis. The most commonly utilized biopsy techniques are either open biopsy or imaging-guided core biopsy [18]. Fine needle aspiration (FNA) has not classically been used due to a smaller tissue sample and lack of tissue architecture. However, several studies have established the usefulness of FNA in providing accurate diagnosis through the new technology of immunocytochemistry, DNA flow cytometry and molecular genetic studies [18-21]. The use of a minimally invasive technique is preferred as it minimizes the procedure-related risk and danger of malignant cell dissemination during percutaneous biopsy [18]. Needle track biopsy should be reserved for cases not amenable to surgical resection [22,23].

Several approaches are used to confirm the diagnosis of ES/PNET. The first approach is light microscopic examination of tumor tissue including immunohistochemistry. These tumors consist of primitive-appearing round cells with high nucleus-to-cytoplasm ratios. The immunohistochemical features of ES/PNET are positive for CD99 (a 32-kDa cell surface glycoprotein encoded by the MIC2 gene); however, expression of CD99 is by no means specific for ES/PNET among round-cell tumors. Although FLI-1 is a variable histochemical marker for ES/PNET, it is also positive in lymphoblastic lymphoma. In contrast, Wilms' tumor gene (WT1) is a positive marker of Wilms' tumor and desmoplastic round-cell tumors, whereas it is a negative marker for ES/PNET, neuroblastoma and rhabdomyosarcoma.

The second approach is electron microscopic examination of tumor tissue. Electron microscopic features include a specific high nucleus-to-cytoplasm ratio and aggregated glycogen granules in the cytoplasm. Neural differentiation appears on some cells with polar processes, which may contain microtubules or neurosecretory glands.

The third approach are molecular genetic studies by polymerase chain reaction (RTPCR) or FISH to detect chromosomal translocation, such as $t(11 ; 22)(q 24 ; q 12)$ which is positive in $88-95 \%$ of ES/PNET cases.

The final approach involves a molecular biologic examination. In $90-95 \%$ of cases of ES/PNET, the chimeric transcript, an aberrant fusion protein, is called EWS-FLI-1. Other transcripts have also been reported [24-26]. As many as 20\% of ES exhibit additional more complex chromosomal arrangements [11].

\section{Treatment of EO ES}

Treatment of EO ES consists of a multimodality care in a specialized center. There is a different approach for localized and metastatic disease.

\section{Localized Disease}

The golden standard of treatment is surgery. There is no potential for cure in sarcoma patients without margin-negative surgery [27-30]. Chemotherapy is provided after surgery to improve overall survival rates and reduce the likelihood of tumor recurrence [31]. A combination of several agents is used to obtain a higher response rate [7]. First-generation regimens consisted of the combination of vincristine, cyclophosphamide, actinomycin D and doxorubicin (VAcCD). Second-generation regimens incorporated ifosfamide and later 
etoposide with improved disease-free survival for patients with localized disease. The current generation of clinical trials has attempted to improve survival by maximizing the chemotherapy dose per cycle, increasing the total number of cycles provided, or decreasing the interval between cycles ('dose-dense' therapies) [1].

ES is quite radiosensitive, but improvements in surgical technique and the risks associated with radiation (secondary malignancies) have reduced the reliance upon radiation. Radiation therapy is an option to achieve longer disease-free survival rates or to obtain local control [7].

Recurrent and Metastatic Disease

The preferred treatment of localized recurrent disease is surgical excision if it is possible to achieve negative margins. Metastatic disease or unresectable recurrent disease demands another approach. The only option is chemotherapy, as most patients have had radiotherapy before.

Whereas the combination of surgery and chemotherapy often enables patients with localized disease to be cured, in those with metastatic spread the benefit of chemotherapy is more often limited to extending progression-free survival. Durable responses remain elusive [32-35].

Patients with pulmonary metastases are mostly treated with chemotherapy. Surgical resection is an option to achieve local control and some data suggest a better overall survival [8].

Palliative radiation therapy can be given to alleviate the patients' symptoms (pain or bleeding).

New Possibilities

The latest generation of conventional cytotoxic chemotherapies in use for ES appears to be unable to improve the survival in patients with metastatic or recurrent disease [7]. A number of biologically targeted therapies are transitioning from the laboratory for evaluation in early-phase human clinical trials to gain a new therapeutic approach [1]. For instance, one of the most promising drug targets is the insulin-like growth factor-1 receptor (IGF-1R) [36]. This receptor is found to play an essential role in the pathogenesis of ES.

\section{Extraosseous Ewing's Sarcoma}

EO ES arising in the omentum of the abdomen is extremely rare. To our knowledge, this entity has only been described once [13]. Other cases with an EO ES in the mesocolon [14], a male with an acute abdominal EO ES next to the left colon [37], EO ES in the liver [38] and EO ES in the small intestine $[10,39]$ have been described. This case indicates that EO ES should be included in the differential diagnosis of lesions arising in the omentum.

\section{Conclusion}

EO ES in the omentum of the abdomen is an infrequent location of this tumor. We report the second case in the literature. EO ES should be included in the differential diagnosis of lesions arising in the omentum. Multimodality care in a specialized center, consisting of surgery and chemotherapy, is needed to ensure the patient's best outcome. 


\section{References}

1 Ludwig JA: Ewing sarcoma: historical perspectives, current state-of-the-art, and opportunities for targeted therapy in the future. Curr Opin Oncol 2008;20:412-418.

$>2$ Lewis TB, Coffin CM, Bernard PS: Differentiating Ewing's sarcoma from other round blue-cell tumors using a RT-PCR translocation panel on formalin-fixed paraffin-embedded tissues. Mod Pathol 2007;20:397-404.

-3 Delattre O, Zucman J, Melot T, Garau XS, Zucker JM, Lenoir GM, Ambros PF, Sheer D, Turc-Carel C, Triche TJ: The Ewing family of tumors - a subgroup of small-round-cell tumors defined by specific chimeric transcripts. N Engl J Med 1994;331:294-299.

-4 Herzog CE: Overview of sarcomas in the adolescent and young adult population. J Pediatr Hematol Oncol 2005;27:215-218.

5 Parkin DM, Stiller CA, Nectoux J: International variations in the incidence of childhood bone tumours. Int J Cancer 1993;53:371-376.

-6 Cotterill SJ, Ahrens S, Paulussen M, Jürgens HF, Voûte PA, Gadner H, Craft AW: Prognostic factors in Ewing's tumor of bone: analysis of 975 patients from the European Intergroup Cooperative Ewing's Sarcoma Study Group. J Clin Oncol 2000;18:3108-3114.

7 Subbiah V, Anderson P, Lazar AJ, Burdett E, Raymond K, Ludwig JA: Ewing's sarcoma: standard and experimental treatment options. Curr Treat Options Oncol 2009;10:126-140.

8 Letourneau PA, Shackett B, Xiao L, Trent J, Tsao KJ, Lally K, Hayes-Jordan A: Resection of pulmonary metastases in pediatric patients with Ewing sarcoma improves survival. J Pediatr Surg 2011;46:332-335.

-9 McManus AP, Gusterson BA, Pinkerton CR, Shipley JM: The molecular pathology of small round-cell tumours - relevance to diagnosis, prognosis, and classification. J Pathol 1996;178:116-121.

10 Shek TW, Chan GC, Khong PL, Chung LP, Cheung AN: Ewing sarcoma of the small intestine. J Pediatr Hematol Oncol 2001;23:530-532.

11 Maeda M, Tsuda A, Yamanishi S, Uchikoba Y, Fukunaga Y, Okita H, Hata JI: Ewing sarcoma/primitive neuroectodermal tumor of the kidney in a child. Pediatr Blood Cancer 2008;50:180-183.

12 Park JY, Lee S, Kang HJ, Kim HS, Park SY: Primary Ewing's sarcoma-primitive neuroectodermal tumor of the uterus: a case report and literature review. Gynecol Oncol 2007;106:427-432.

13 Tanida S, Tanioka F, Inukai M, Yoshioka N, Saida Y, Imai K, Nakamura T, Kitamura H, Sugimura H: Ewing's sarcoma/peripheral primitive neuroectodermal tumor (pPNET) arising in the omentum as a multilocular cyst with intracystic hemorrhage. J Gastroenterol 2000;35:933-940.

14 Maisonnette F, Roux ET, Abita T, Martin S, Pommepuy I, Durand-Fontanier S, Valleix D, Descottes B, Pillegand B: Ewing sarcoma of the mesocolon. Gastroenterol Clin Biol 2007;31:552-554.

15 Petković M, Zamolo G, Muhvić D, Coklo M, Stifter S, Antulov R: The first report of extraosseous Ewing's sarcoma in the rectovaginal septum. Tumori 2002;88:345-346.

16 Taylor BS, Barretina J, Maki RG, Antonescu CR, Singer S, Ladanyi M: Advances in sarcoma genomics and new therapeutic targets. Nat Rev Cancer 2011;11:541-557.

17 Hart MN, Earle KM: Primitive neuroectodermal tumors of the brain in children. Cancer 1973;32:890-897.

18 Sofi AA, Thekdi AD, Nawras A: EUS-FNA for the diagnosis of retroperitoneal primitive neuroectodermal tumor. Diagn Ther Endosc 2011;2011:198029.

19 Guiter GE, Gamboni MM, Zakowski MF: The cytology of extraskeletal Ewing sarcoma. Cancer 1999;87:141148.

20 Brahmi U, Rajwanshi A, Joshi K, Ganguly NK, Vohra H, Gupta SK, Dey P: Role of immunocytochemistry and DNA flow cytometry in the fine-needle aspiration diagnosis of malignant small round-cell tumors. Diagn Cytopathol 2001;24:233-239.

-21 Sanati S, Lu DW, Schmidt E, Perry A, Dehner LP, Pfeifer JD: Cytologic diagnosis of Ewing sarcoma/peripheral neuroectodermal tumor with paired prospective molecular genetic analysis. Cancer 2007;111:192-199.

-22 Rowe LR, Mulvihill SJ, Emerson L, Gopez EV: Subcutaneous tumor seeding following needle core biopsy of hepatocellular carcinoma. Diagn Cytopathol 2007;35:717-721.

23 John TG, Garden OJ: Needle track seeding of primary and secondary liver carcinoma after percutaneous liver biopsy. HPB Surg 1993;6:199-203, discussion 203-204.

24 Desmaze C, Zucman J, Delattre 0, Thomas G, Aurias A: Unicolor and bicolor in situ hybridization in the diagnosis of peripheral neuroepithelioma and related tumors. Genes Chromosomes Cancer 1992;5:30-34.

25 Zucman J, Delattre O, Desmaze C, Plougastel B, Joubert I, Melot T, Peter M, De Jong P, Rouleau G, Aurias A: Cloning and characterization of the Ewing's sarcoma and peripheral neuroepithelioma $t(11 ; 22)$ translocation breakpoints. Genes Chromosomes Cancer 1992;5:271-277.

26 Delattre O, Zucman J, Plougastel B, Desmaze C, Melot T, Peter M, Kovar H, Joubert I, de Jong P, Rouleau G: Gene fusion with an ETS DNA-binding domain caused by chromosome translocation in human tumours. Nature 1992;359:162-165.

27 Schuck A, Ahrens S, Paulussen M, Kuhlen M, Könemann S, Rübe C, Winkelmann W, Kotz R, Dunst J, Willich N, Jürgens H: Local therapy in localized Ewing tumors: results of 1,058 patients treated in the CESS 81, CESS 86, and EICESS 92 trials. Int J Radiat Oncol Biol Phys 2003;55:168-177. 
28 Bacci G, Forni C, Longhi A, Ferrari S, Donati D, De Paolis M, Barbieri E, Pignotti E, Rosito P, Versari M: Longterm outcome for patients with non-metastatic Ewing's sarcoma treated with adjuvant and neoadjuvant chemotherapies. 402 patients treated at Rizzoli between 1972 and 1992. Eur J Cancer 2004;40:73-83.

-29 Donaldson SS, Torrey M, Link MP, Glicksman A, Gilula L, Laurie F, Manning J, Neff J, Reinus W, Thompson E, Shuster JJ: A multidisciplinary study investigating radiotherapy in Ewing's sarcoma: end results of POG \#8346. Pediatric Oncology Group. Int J Radiat Oncol Biol Phys 1998;42:125-135.

-30 Krasin MJ, Rodriguez-Galindo C, Billups CA, Davidoff AM, Neel MD, Merchant TE, Kun LE: Definitive irradiation in multidisciplinary management of localized Ewing sarcoma family of tumors in pediatric patients: outcome and prognostic factors. Int J Radiat Oncol Biol Phys 2004;60:830-838.

-31 Falk S, Alpert M: Five-year survival of patients with Ewing's sarcoma. Surg Gynecol Obstet 1967;124:319324.

-32 Saylors RL, Stine KC, Sullivan J, Kepner JL, Wall DA, Bernstein ML, Harris MB, Hayashi R, Vietti TJ: Cyclophosphamide plus topotecan in children with recurrent or refractory solid tumors: a Pediatric Oncology Group phase II study. J Clin Oncol 2001;19:3463-3469.

33 Hunold A, Weddeling N, Paulussen M, Ranft A, Liebscher C, Jürgens H: Topotecan and cyclophosphamide in patients with refractory or relapsed Ewing tumors. Pediatr Blood Cancer 2006;47:795-800.

34 Wagner LM, Crews KR, Iacono LC, Houghton PJ, Fuller CE, McCarville MB, Goldsby RE, Albritton K, Stewart $\mathrm{CF}$, Santana VM: Phase I trial of temozolomide and protracted irinotecan in pediatric patients with refractory solid tumors. Clin Cancer Res 2004;10:840-848.

-35 Wagner LM, McAllister N, Goldsby RE, Rausen AR, McNall-Knapp RY, McCarville MB, Albritton K: Temozolomide and intravenous irinotecan for treatment of advanced Ewing sarcoma. Pediatr Blood Cancer 2007;48:132-139.

-36 Tao Y, Pinzi V, Bourhis J, Deutsch E: Mechanisms of disease: signaling of the insulin-like growth factor 1 receptor pathway - therapeutic perspectives in cancer. Nat Clin Pract Oncol 2007;4:591-602.

-37 Valdivia Gómez GG, Soto Guerrero MT, Cedillo de la Cruz MI: Extra-skeletal Ewing's sarcoma resembling acute abdomen. Case report. Cir Cir 2010;78:159-162.

38 Huang SF, Chiang JH, Jan HC, Chou SJ, Chen TK, Chen TH: Intra-abdomen Ewing's sarcoma. ANZ J Surg 2011;81:377-378.

-39 Takahashi H, Chida N, Kimura K, Yamao Y, Shiotuka K, Ritsuno H, Awabuchi S, Akoshima H, Sugimura M, Noguchi K, Tanabe N, Iwabuchi M, Mano Y, Tadokoro K, Suzuki H: A case report of Ewing's sarcoma with a peripheral primitive neuroectodermal tumor (ES/pPNET) in the abdominal cavity. Nihon Shokakibyo Gakkai Zasshi 2009;106:1524-1530. 
Table 1. Taxonomy of soft tissue sarcoma [16]

\begin{tabular}{ll}
\hline Adipocytic & Myxoid/round-cell, pleomorphic, dedifferentiated and well-differentiated liposarcoma \\
\hline Chondro-osseous & Mesenchymal chondrosarcoma and extraskeletal osteosarcoma \\
\hline $\begin{array}{l}\text { Fibroblastic or } \\
\text { myofibroblastic }\end{array}$ & $\begin{array}{l}\text { Adult fibrosarcoma, low-grade fibromyxoid sarcoma, myxofibrosarcoma, sclerosing } \\
\text { epithelioid fibrosarcoma } \\
\text { Congenital fibrosarcoma, inflammatory myofibroblastic tumor, low-grade myofibro- } \\
\text { blastic sarcoma } \\
\text { Dermatofibrosarcoma protuberans, solitary fibrous tumor-hemangiopericytoma, } \\
\text { myxoinflammatory fibroblastic sarcoma, superficial fibromatoses, desmoid-type } \\
\text { fibromatoses }\end{array}$ \\
\hline Fibrohistiocytic & $\begin{array}{l}\text { Giant-cell tumor of soft tissues, plexiform fibrohistiocytic tumor, giant-cell, inflammato- } \\
\text { ry and pleomorphic MFH }\end{array}$ \\
\hline Nerve sheath & Malignant peripheral nerve sheath tumor \\
\hline Pericytic & Malignant myopericytoma and malignant glomus tumor \\
\hline Skeletal muscle & Pleomorphic, sclerosing, spindle-cell, embryonal and alveolar rhabdomyosarcoma \\
\hline Smooth muscle & Gastrointestinal stromal tumor, deep-seated/visceral and cutaneous leiomyosarcoma \\
\hline $\begin{array}{l}\text { Uncertain } \\
\text { differentiation }\end{array}$ & $\begin{array}{l}\text { Mixed tumor/myoepithelioma, chordoma periphericum, ossifying fibromyxoid tumor } \\
\text { Epithelioid sarcoma, extra-renal rhabdoid tumor, intimal sarcoma, malignant } \\
\text { mesenchymoma and perivascular epithelioid cell neoplasm } \\
\text { Angiomatoid fibrous histiocytoma, alveolar soft part sarcoma, synovial and clear cell } \\
\text { sarcoma, desmoplastic small round-cell tumor, ES and PNET, extraskeletal myxoid } \\
\text { chondrosarcoma }\end{array}$ \\
\hline $\begin{array}{l}\text { Epithelioid hemangioendothelioma, angiosarcoma, Kaposi's sarcoma, retiform, } \\
\text { composite and kaposiform hemangioendothelioma }\end{array}$ \\
\hline
\end{tabular}




\section{Case Reports in Oncology}

\begin{tabular}{l|l}
\hline Case Rep Oncol 2013;6:293-302 \\
\hline DOI: $10.1159 / 000351836$ & $\begin{array}{l}\text { @ } 2013 \text { S. Karger AG, Basel } \\
\text { www.karger.com/cro }\end{array}$ \\
\hline
\end{tabular}

Geens et al.: An Unusual Location of Extraosseous Ewing's Sarcoma

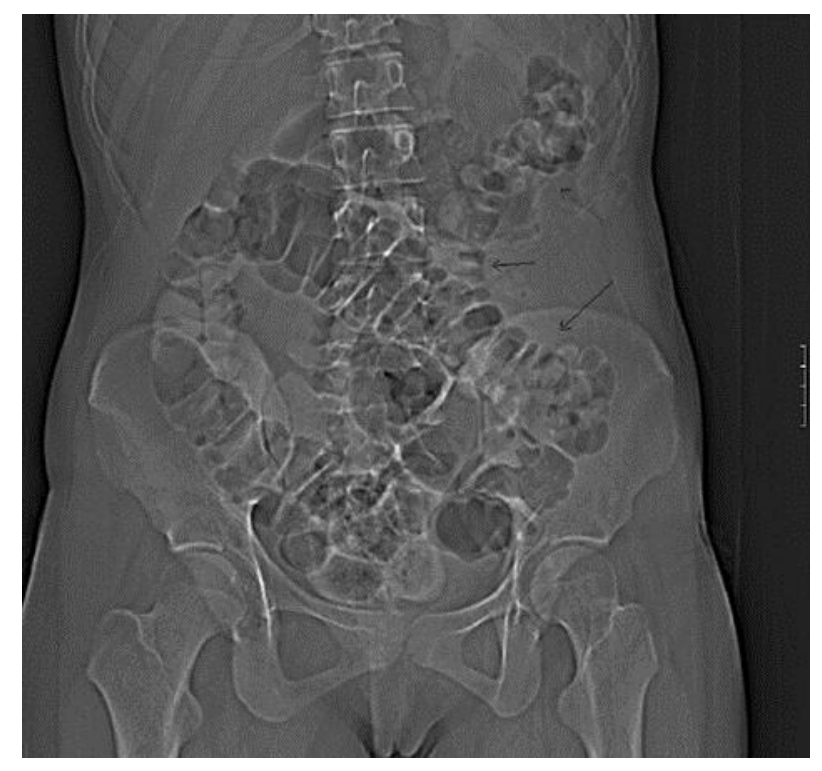

Fig. 1. CT scout view. The lesion caused a displacement of the descending colon to a more medial position (arrows).

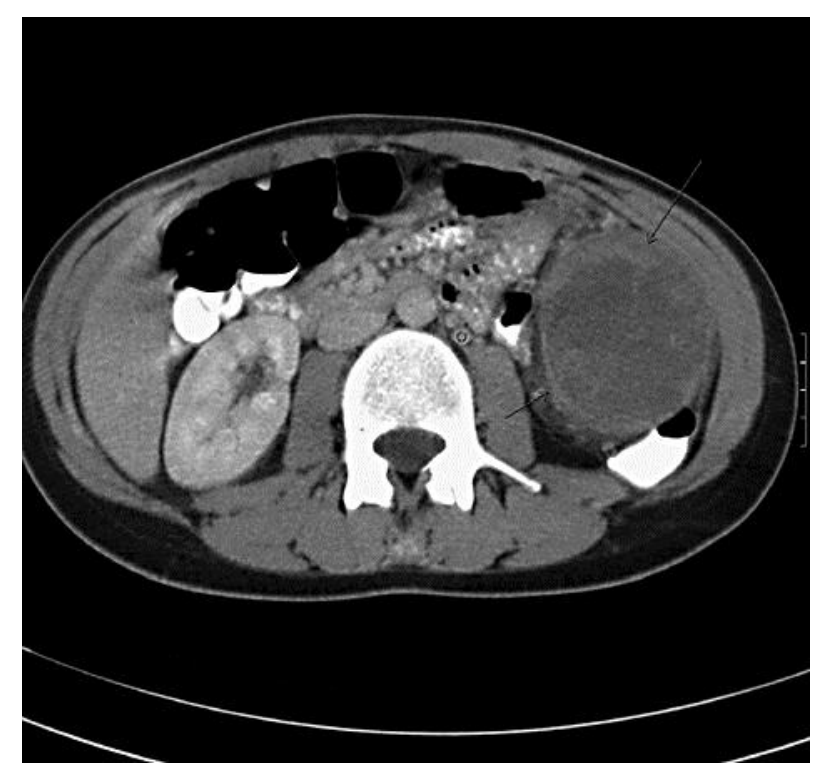

Fig. 2. CT in the axial plane after intravenous administration of iodinated contrast. There was contrast uptake by the lesion in the portal venous phase, predominantly in the periphery of the lesion. The tumor was hypovascular in the arterial phase of contrast perfusion (not shown). Small areas of intralesional necrosis were present. The peripheral margin of the lesion was blurry (arrows). These characteristics were suspicious for a malignant biological behavior of the tumor. Dilatation of the left gonadal vein was seen $\left({ }^{\circ}\right)$ due to extrinsic compression. 


\section{Case Reports in Oncology}

\begin{tabular}{l|l}
\hline Case Rep Oncol 2013;6:293-302 & \\
\hline DOI: $10.1159 / 000351836$ & $\begin{array}{l}\text { ○ 2013 S. Karger AG, Basel } \\
\text { www.karger.com/cro }\end{array}$ \\
\hline
\end{tabular}

Geens et al.: An Unusual Location of Extraosseous Ewing's Sarcoma

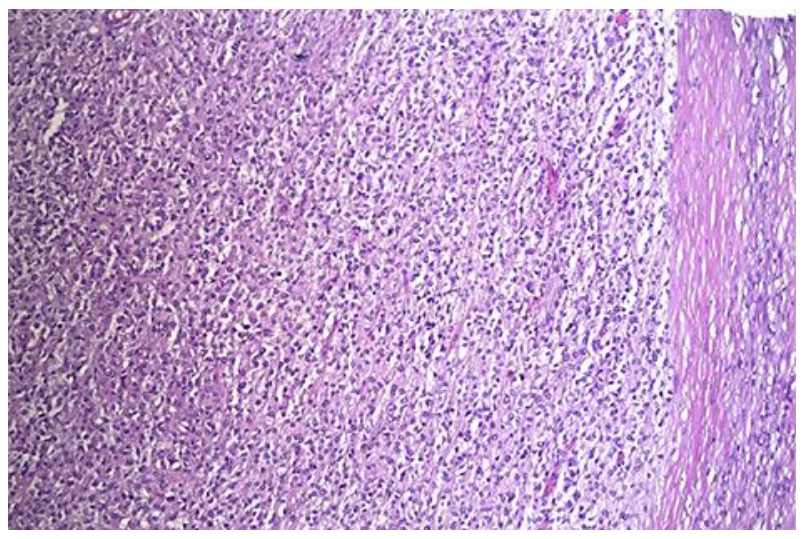

Fig. 3. Light microscopic picture. Hematoxylin-eosin staining; $\times 10$. Left: tumor cells closely packed together. Right: capsule.

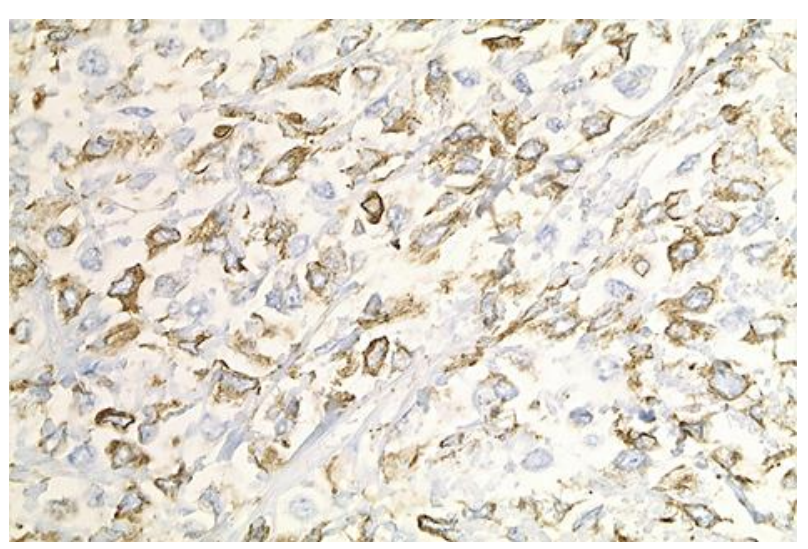

Fig. 4. Immunohistochemical staining; vimentin-positive cells; $\times 40$.

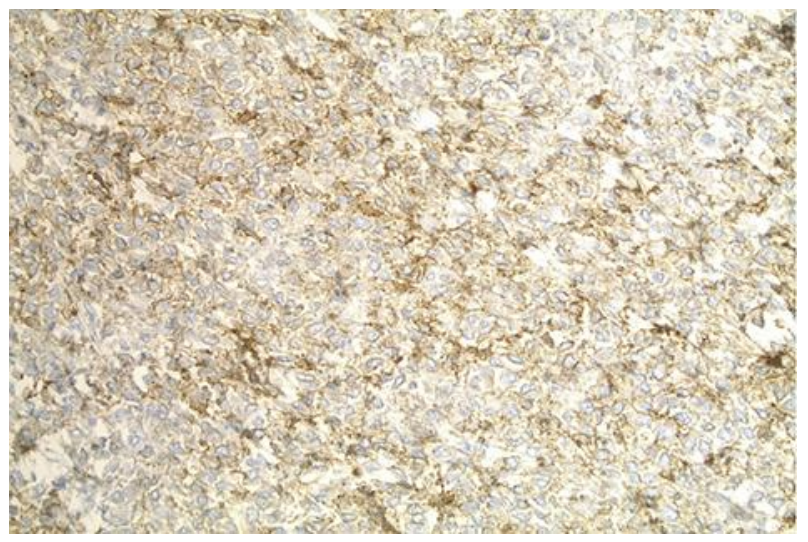

Fig. 5. Immunohistochemical staining; CD99-positive cells; $\times 20$. 